\title{
Parametric study of die sinking EDM process on AISI H13 tool steel using statistical techniques
}

\author{
Bose, G.K. ${ }^{\mathrm{a},}{ }^{*}$, Mahapatra, K.K. ${ }^{\mathrm{b}}$ \\ ${ }^{a}$ Department of Mechanical Engineering, Haldia Institute of Technology, Haldia, India \\ ${ }^{\mathrm{b}}$ Technical Service, Central Institute of Plastic Engineering Technology, Bhubaneswar, India
}

\begin{abstract}
A B S T R A C T
The correct optimization of process parameters is one of the more important aspects when taking into consideration the majority of manufacturing processes and particularly for processes relating to electrical discharge machining (EDM). It is capable of machining geometrically complex or hard material components that are precise and difficult-to-machine, such as heat-treated tool steels, composites, super alloys, ceramics, carbides, heat resistant steels etc. The presented study focused on the electric discharge machining (EDM) of AISI H 13, W.-Nr. 1.2344 Grade: Orvar Supreme for finding out the effect of machining parameters such as discharge gap current (GI), pulse on time (POT), pulse off time (POF) and spark gap (SG) on performance responses such as material removal rate (MRR), surface roughness $\left(R_{a}\right)$ and overcut (OC) using a square-shaped $\mathrm{Cu}$ tool with lateral flushing. A well-designed experimental scheme was used to reduce the total number of experiments. Parts of the experiment were conducted within the L27 orthogonal array based on the Taguchi method and significant process parameters were identified using analysis of variance (ANOVA). It was found that MRR is affected by gap current and $R a$ is affected by pulse on time. Moreover, the signal-to-noise ratios associated with the observed values in the experiments were determined by which factor was most affected by the responses of MRR, $R_{a}$ and OC. These experimental data are investigated using response surface methodology (RSM) for the effects of four EDM parameters GI, POT, POF and SG on MRR, $R_{a}$ and OC. Response surfaces and contour plots were considered for exploring the importance of the variables and their levels, so as to optimize the responses. Finally multi-response optimization was carried out by means of overlaid contour plots and desirability functions.
\end{abstract}

\section{ARTICLE INFO}

Keywords:

Die sinking EDM

Multi response optimization

Analysis of variance

Response surface methodology

*Corresponding author:

gkbose@yahoo.com

(Bose, G.K.)

Article history:

Received 29 June 2014

Revised 4 November 2014

Accepted 10 November 2014 


\section{References}

[1] Selvakumar, G., Sarkar, S., Mitra, S. (2013). An experimental analysis of single pass cutting of aluminium 5083 alloy in different corner angles through WEDM, International Journal of Machining and Machinability of Materials, Vol. 13, No. 2/3, 262-275, doi: 10.1504/IJMMM.2013.053227.

[2] Kapoor, J., Khamba, J.S., Singh, S. (2012). The effect of machining parameters on surface roughness and material removal rate with cryogenic treated wire in WEDM, International Journal of Machining and Machinability of Materials, Vol. 12, No. 1/2, 126-141, doi: 10.1504/IJMMM.2012.048562.

[3] Dvivedi, A., Kumar, P., Singh, I. (2010). Effect of EDM process parameters on surface quality of Al $6063 \mathrm{SiC}_{\mathrm{p}}$ metal matrix composite, International Journal of Materials and Product Technology, Vol. 39, No. 3/4, 357-377.

[4] Aligiri, E., Yeo, S.H., Tan, P.C., Zarepour, H. (2010). Benefits of using real-time pulse discriminating system in micro-EDM monitoring and control system, International Journal of Mechatronics and Manufacturing Systems, Vol. 3, No. 5/6, 466-481, doi: 10.1504/IJMMS.2010.036070.

[5] Liu, H.S., Tarng, Y.S. (1997). Monitoring of the electrical discharge machining process by abductive networks, The International Journal of Advanced Manufacturing Technology, Vol. 13, No. 4, 264-270, doi: 10.1007/ BF01179608.

[6] Ayesta, I., Izquierdo, B., Sánchez, J.A., Ramos, J.M., Plaza, S., Pombo, I., Ortega, N., Bravo, H., Fradejas, R., Zamakona, I. (2013). Influence of EDM parameters on slot machining in C1023 aeronautical alloy, In: Lauwers, B., Kruth, J.-P. (eds.), Procedia CIRP, Proceedings of the Seventeenth CIRP Conference on Electro Physical and Chemical Machining (ISEM), Vol. 6, Elsevier, 129-134, doi: 10.1016/j.procir.2013.03.059.

[7] Nipanikar, S.R. (2012). Parameter optimization of electro discharge machining of AISI D3 steel material by using Taguchi method, Journal of Engineering Research and Studies, Vol. 3, No. 3, 7-10.

[8] Ben Salem, S., Tebni, W., Bayraktar, E. (2011). Prediction of surface roughness by experimental design methodology in electrical discharge machining (EDM), Journal of Achievements in Materials and Manufacturing Engineering, Vol. 49, No. 2, 150-157.

[9] Singh, K., Kalra, C.S. (2013). An experimental investigation: machining of OHNS steel by EDM, Journal of Engineering Computers and Applied Sciences, Vol. 2, No. 6, 39-42.

[10] Syed, K.H., Palaniyandi, K., (2012). Performance of electrical discharge machining using aluminium powder suspended distilled water, Turkish Journal of Engineering and Environmental Science, Vol. 36, 195-207, doi: 10.3906/muh-1202-2.

[11] Kumar, A., Kumar, V., Kumar, J. (2012). Prediction of surface roughness in wire electric discharge machining (WEDM) process based on response surface methodology, International Journal of Engineering and Technology, Vol. 2, No. 4, 708-719.

[12] Kohli, A., Wadhwa, A., Virmani, T., Jain, U. (2012). Optimization of material removal rate in electrical discharge machining using fuzzy logic, World Academy of Science, Engineering and Technology, Vol. 6, No. 12, 1509-1514.

[13] Mohanty, C.P., Sahu, J., Mahapatra, S.S. (2013). Thermal-structural analysis of electrical discharge machining process, In: Mehta, U. (ed.), Procedia Engineering, Chemical, Civil and Mechanical Engineering Tracks of $3^{\text {rd }}$ Nirma University International Conference on Engineering, Vol. 51, 508-513, doi: 10.1016/j.proeng.2013.01.072.

[14] Arikatla, S.P., Krishnaiah, A., Mannan, K.T. (2013). Optimization of electric discharge machining response variables using design of experiments, International Journal of Mechanical and Production Engineering, Vol. 2 No. 1, 82-87.

[15] Baseri, H., Aliakbari, E., Alinejad, G. (2012). Investigation of the rotary EDM process of X210Cr12, International Journal of Machining and Machinability of Materials, Vol. 11, No. 3, 297-307.

[16] Park, S.H. (1996). Robust design and analysis for quality engineering, Chapman and Hall, London.

[17] Montgomery, D.C. (2000). Design and analysis of experiments, Fifth edition, John Wiley \& Sons, New York. 


\title{
APEM
}

\section{Parametrična analiza potopne elektroerozije pri obdelavi orodnega jekla AISI H13 z uporabo statističnih tehnik}

\author{
Bose, G.K. ${ }^{a}{ }^{*}$, Mahapatra, K.K. ${ }^{b}$ \\ ${ }^{a}$ Department of Mechanical Engineering, Haldia Institute of Technology, Haldia, India \\ ${ }^{\mathrm{b}}$ Technical Service, Central Institute of Plastic Engineering Technology, Bhubaneswar, India
}

\section{POVZETEK}

Pri večini obdelovalnih postopkov je vitalnega pomena pravilna nastavitev procesnih parametrov, še posebej pa pri obdelavah s postopkom elektroerozije (angl. Electrical Discharge Machining - EDM). Z njim je mogoče natančno obdelati geometrijsko zahtevne oblike iz materialov z visoko trdoto, ki jih je sicer težko obdelovati. Taki materiali so npr. toplotno obdelana orodna jekla, kompoziti, super zlitine, keramike, karbidi, toplotno obstojna jekla itd. Pričujoča raziskava je bila namenjena študiju obdelave orodnega jekla AISI H 13 , W.-Nr. $1.2344 \mathrm{~s}$ postopkom elektroerozije. Želeli smo ugotoviti vpliv obdelovalnih parametrov, kot so tok v reži (GI), čas impulza (POT), čas pavze (POF) in velikost reže (SG), na učinkovitost postopka, kot so stopnja odvzema materiala (MRR), površinska hrapavost $\left(R_{a}\right)$ in obdelava nad predvideno nominalno mero (angl. Overcut - OC). Uporabili smo pravokotno bakreno orodje s stranskim dovajanjem dielektrika. Z dobro načrtovanim eksperimentalnim delom smo zmanjšali potrebno število eksperimentov. Ti so bili izvedeni $\mathrm{v}$ skladu z L27 ortogonalno matriko, temelječo na Taguchi metodi. Signifikantni procesni parametri so bili ugotovljeni z metodo analize variance (ANOVA). Ugotovili smo, da tok v reži vpliva na MRR, čas impulza pa na $R_{a}$. Poleg tega smo z razmerji signal/šum in ustreznimi eksperimentalnimi podatki ugotovili tiste vplivne parametre, ki najbolj vplivajo na MRR, $R_{a}$ in OC. Eksperimentalne podatke smo raziskali $\mathrm{z}$ metodologijo odzivnih površin (angl. Response Surface Methodology - RSM) in ugotavljali vpliv štirih procesnih parametrov elektroerozijskega postopka (tj. GI, POT, POF in SG) na MRR, $R_{a}$ in OC. Za ugotavljanje pomembnosti procesnih parametrov in $\mathrm{s}$ tem optimiranje odziva, smo uporabili odzivne površine in konturne diagrame. Na koncu smo izvedli še optimizacijo z ozirom na več odzivov s pomočjo konturnih diagramov in t. i. funkcij želja (angl. Desirability Functions).

\section{PODATKI O ČLANKU}

Ključne besede:

Potopna elektroerozija

Optimizacija na več odzivov

Analiza variance

Metodologija odzivnih površin

* Kontaktna oseba: gkbose@yahoo.com (Bose, G.K.)

Zgodovina članka: Prejet 29. junija 2014

Popravljen 4. novembra 2014

Sprejet 10. novembra 2014 